\title{
Do All Intellectual Capital Dimension \\ Affects Innovation Capability? \\ (Evidence from Indonesian Food and Beverage Industry)
}

\author{
Dian Mayastika Molthar ${ }^{1}$ and Nurul Indarti ${ }^{2}$ \\ ${ }^{1}$ Management Department, Faculty of Economy \\ Universitas Kristen Immanuel
}

${ }^{2}$ Management Department, Faculty of Economics and Business Universitas Gadjah Mada

\begin{abstract}
maya@ukrimuniversity.ac.id
\end{abstract}
\begin{abstract}
Using a survey in 120 companies in the food and beverage industry such restaurants and café, manufacture, and retail in Indonesia, this study discusses the effect of intellectual capital on innovation capability. The results prove that not all of intellectual capital dimension support innovation capability. Structural capital and relational capital are knowledge assets that play an important role for the company's ability to innovate. In addition, other findings from this study reveal that human capital has no significant effect on innovation capability. That is because in the context of three companies in the food and beverage industry in Indonesia, the innovation decision is not related to the employee or human capital aspects. Furthermore, this research also has not been able to prove that relational capital moderates the positive influence of human capital on innovation capability. That is because the formation of human capital aspects such skills of employees in this industry are not related to the relations and collaboration of the company.
\end{abstract}

Keywords: human capital; structural capital; relational capital, innovation capability

\begin{tabular}{ll}
\hline JEL & $:$ M3 \\
DOI & $: 10.24002 /$ kinerja.v25i1.4208
\end{tabular}

Received : 02/04/2021 Reviewed: 02/11/2021_Final Version: 03/09/2021

\section{INTRODUCTION}

In the era of knowledge-based competition, competitive advantage is obtained through the creation of new knowledge from the unique combination of companies (Fleming, 2001) such as intellectual capital. Intellectual capital is intellectual material in the form of knowledge, information, intellectual property 
rights, and company experiences that can be used to create value (Stewart, 1998) and produce innovation (Lev, 2001). Intellectual capital consists of human capital, structural capital, and relational capital (Andreeva and Garanina, 2016; Cabrita and Bontis, 2008; Cleary and Quinn, 2016; Fan and Lee, 2016; Guthrie and Petty, 2000; Roos et al., 1997) which is a source of corporate innovation (Mention, 2012).

This study aims to examine the positive effect of three dimensions of intellectual capital namely human capital (i.e., competences and skills), structural capital (i.e., systems and databases), and relational capital (i.e., networks or relationships) on the ability of corporate innovation. This is due to several reasons as follows. First, the relationship between intellectual capital and innovation capability requires more empirical research (Buenechea-Elberdin, 2017; Wu and Sivalogathasan, 2013). Second, previous research on intellectual capital and innovation (i.e., Carmona-Lavado, Cuevas-Rodríguez, and Cabello-Medina, 2013; Hsu and Fang, 2009; Leitner, 2011) only focused on intellectual capital not on the impact that can be driven by intellectual capital towards innovation (Dumay et al., 2015; Ferenhof et al., 2015).

Third, a literature study by Buenechea-Elberdin (2017) suggests that intellectual capital research only focuses on manufacturing companies. More disclosure is needed about how intellectual capital works in manufacturing and service companies (Mention, 2012). Fourth, there are inconsistent results of previous research about contribution of intellectual capital dimensions to the creation of corporate value. For example, Nanggong and Indarti (2016) found a positive relationship between human resources and innovation, while Subramaniam and Youndt (2005) found human capital to negatively affect a company's ability to innovate.

Furthermore, research by Zerenler et al. (2008) have also linked industry growth to the existence of intellectual capital in companies, where the positive effect of intellectual capital on overall innovation performance will be greater in industries with high growth rates. In Indonesia, the food and beverage industry is one of the important sectors for the national economy because it continues to experience significant growth (Ministry of Industry, 2017). Gross domestic product (GDP) of the food and beverage industry in 2016 reached IDR 586,5 trillion or 6,2 percent of the total national gross domestic product worth IDR 9,433 trillion1. Therefore, this research is focused on the food and beverage industry.

In the Indonesian context, industrial grouping refers to the standard classification of Indonesian Industrial Origin (Klasifikasi Baku Lapangan Usaha Indonesia) where the food and beverage industry consists of the processing industry subsector and the provision of accommodation and food and beverage supplies (Central Bureau of Statistic, 2015). Companies in the manufacturing industry subsector are manufacturing and retailing (Central Bureau of Statistic, 2015), while the provision of accommodation and provision of food and beverage subsector is restaurant and café. Thus, this research was conducted on three companies in the food and beverage industry, namely restaurants and café, manufacturing, and retail.

\footnotetext{
${ }^{1}$ Data of the food and beverage industry growth on national GDP is based on data published by Katadata Indonesia. https://databoks.katadata.co.id/datapublish/2018/01/30/industri-makanan-dan-minum-tumbuh-di-atas-pdbnasional (30 January 2018) (new access at 5 Mei 2018)
} 
Based on the latest data from the Ministry of Tourism and Creative Economy (2014) since 2007 to 2011, around 70 percent of restaurants are located in Java. Study by Amelia et al. (2017) also states that food and beverage manufacturing companies in Java are at the highest percentage $(69,73$ percent) compared to other regions in Indonesia. These data provide information that the competition for the food and beverage industry in Indonesia is concentrated in Java.

The rest of the paper is organized as follows. In the next section, the authors provide a detailed literature review, followed by the development of research hypothesis. Then data collection, sample description, and variable measurement are presented. The results of the analysis are discussed in Section 5. Finally, conclusions and comments for future research are provided.

\section{LITERATURE REVIEW}

\subsection{Intellectual capital}

According to intellectual capital literature, the definition of intellectual capital can be interpreted as a collection of assets, concept, system, strategy, and process (see Table 1). This study uses intellectual capital's definition as a collection of assets (Bontis, 1999; Kianto et al., 2010; Marzo and Scarpino, 2016) which can be utilized for corporate value creation (Kianto et al., 2010). Collection of assets owned by the company such as experience (Nanggong and Indarti, 2016), information (Bontis, 1999), relations (Marzo and Scarpino, 2016) will have an impact on company performance (Bontis et al., 2000), project success (Handzic and Durmic, 2015) and the innovation capability of the firm (Subramaniam and Youndt, 2005).

Table 1. Definition of Intellectual Capital

\begin{tabular}{|c|c|c|}
\hline Category & Definition & Author \\
\hline $\begin{array}{l}\text { Intellectual capital } \\
\text { as a collection of } \\
\text { assets }\end{array}$ & $\begin{array}{l}\text { Intellectual capital is the basis } \\
\text { of resources for the creation of } \\
\text { corporate values. }\end{array}$ & $\begin{array}{l}\text { Stewart (1998), Bontis (1999), } \\
\text { Roos et al. (1997), Nahapiet and } \\
\text { Ghoshal (1998), Bontis et al. } \\
\text { (2000), Kianto et al. (2010), } \\
\text { Marzo and Scarpino (2016), } \\
\text { Handzic and Durmic (2015). }\end{array}$ \\
\hline $\begin{array}{l}\text { Intellectual capital } \\
\text { as a concept }\end{array}$ & $\begin{array}{l}\text { Intellectual capital is a set of } \\
\text { techniques for the company to } \\
\text { manage the assets better. }\end{array}$ & $\begin{array}{l}\text { Nahapiet and Ghoshal (1998), } \\
\text { Roos et al. (1997). }\end{array}$ \\
\hline $\begin{array}{l}\text { Intellectual capital } \\
\text { as a system }\end{array}$ & $\begin{array}{l}\text { Intellectual capital is connected } \\
\text { with company activities in an } \\
\text { effort to utilize knowledge }\end{array}$ & $\begin{array}{l}\text { Roos et al. (1998), Kianto et al. } \\
\text { (2010), Marzo and Scarpino } \\
(2016) .\end{array}$ \\
\hline $\begin{array}{l}\text { Intellectual capital } \\
\text { as a strategy }\end{array}$ & $\begin{array}{l}\text { Intellectual capital is the tool of } \\
\text { company to measure the } \\
\text { accumulation of wealth and the } \\
\text { goal achievements. }\end{array}$ & $\begin{array}{l}\text { Kaplan dan Norton (1992), Sveiby } \\
\text { (1998), Roos et al. (1998), } \\
\text { Secundo et al. (2018). }\end{array}$ \\
\hline $\begin{array}{l}\text { Intellectual capital } \\
\text { as a process }\end{array}$ & $\begin{array}{l}\text { Intellectual capital is a process } \\
\text { for optimizing information into } \\
\text { company knowledge }\end{array}$ & Bontis (1999), Bontis et al. (2000) \\
\hline
\end{tabular}


Previous studies define intellectual capital into several different dimensions (i.e., Bontis, 1999; Subramaniam and Youndt, s2005; Zerenler et al., 2008; Elsetouhi and Elbeltagi, 2013). Table 2 presents the distribution of intellectual capital dimensions based on the location where the assets are, namely to individuals, systems and relationships.

As shows in Table 2, it can be seen that Bontis (1999) divides intellectual capital into three dimensions, namely human capital, structural capital and customer capital. Subramaniam and Youndt (2005) divide intellectual capital into human capital, organizational capital and social capital. Other research also mentions that intellectual capital consists of human capital, structural capital and relational capital (Andreeva and Garanina, 2016; Chen et al., 2006; Costa et al., 2014). Based on the different dimensions of intellectual capital, this study refers to the dimensions of intellectual capital according to Chen et al., (2006) and Andreeva and Garanina (2016) which divides the dimensions of intellectual capital into human capital, structural capital and relational capital.

Table 2. Dimensions of Intellectual Capital

\begin{tabular}{|c|c|c|}
\hline Category & Dimension & Author \\
\hline $\begin{array}{l}\text { Assets that lie in } \\
\text { individuals in } \\
\text { organization }\end{array}$ & Employee capital & $\begin{array}{l}\text { Bontis (1999), Subramaniam and Youndt } \\
\text { (2005), Chen et al. (2006), Kianto et al. (2010), } \\
\text { Carmona-Lavado et al. (2013), Costa et al. } \\
\text { (2014), Elsetouhi and Elbeltagi (2015), } \\
\text { Andreeva and Garanina (2016). } \\
\text { Zarenler et al. (2008) }\end{array}$ \\
\hline $\begin{array}{l}\text { Assets that are } \\
\text { located in the } \\
\text { system in }\end{array}$ & Structural capital & $\begin{array}{l}\text { Bontis (1999), Chen et al. (2006), Zarenler et al. } \\
\text { (2008), Costa et al. (2014), Andreeva and } \\
\text { Garanina (2016). }\end{array}$ \\
\hline organization & $\begin{array}{l}\text { Organizational } \\
\text { capital }\end{array}$ & $\begin{array}{l}\text { Subramaniam and Youndt (2005), Carmona- } \\
\text { Lavado et al. (2013), Elsetouhi and Elbeltagi } \\
\text { (2015). }\end{array}$ \\
\hline \multirow{3}{*}{$\begin{array}{l}\text { Assets related to } \\
\text { relations and } \\
\text { external parties of } \\
\text { the company }\end{array}$} & Relational capital & $\begin{array}{l}\text { Chen et al. (2006), Costa et al. (2014), } \\
\text { Andreeva and Garanina (2016). }\end{array}$ \\
\hline & Social capital & $\begin{array}{l}\text { Subramaniam and Youndt (2005), Carmona- } \\
\text { Lavado et al. (2013), Elestouhi and Elbeltagi } \\
\text { (2015). }\end{array}$ \\
\hline & Customer capital & $\begin{array}{l}\text { Bontis (1999), Zarenler et al. (2008), Elestouhi } \\
\text { et al. (2015). }\end{array}$ \\
\hline
\end{tabular}

Source: Authors (2018)

Human capital is a dimension of intellectual capital that describes human capabilities in entities that have been formed from a combination of several attributes such as knowledge, abilities, attitudes and relationships (Choo and Bontis, 2002). Structural capital is defined as the infrastructure of a company such as management knowledge systems, information technology systems, managerial, organizational structure, and organizational culture (Bontis, 1999; Chen et al., 2005; Guthrie and Petty, 2000), whereas relational capital is organizational knowledge that refers to networking and collaboration with external parties (Huggins, 2010; Kramer et al., 2011; Tsai, 2001). 


\subsection{Innovation capability}

Previous literature on innovation management has conceptualized innovation based on different definitions (Mention, 2012), for example the definition of innovation as an outcome (Johannessen et al., 2001), innovation as a novelty level (Köhler et al., 2012; Oke, 2007), and innovation as an ability (Lawson and Samson, 2001; Neelyet al., 2001). However, the meaning of innovation is still associated with the company's ability to create something new such as products, services and processes (Tushman and Nadler, 1986). The creation according to Dewar and Dutton (1986) can be done by companies at various levels, namely at the radical level and incremental level.

Innovation at the radical level according to Rogers (2003:380) and Gaynor $(2002: 25)$ is the creation of new values from something that has never existed before. Radical innovation will be reflected in the form of introduction of new products on the market by companies (Varis and Littunen, 2010). Innovations at the incremental level according to Rogers (2003:380) and Gaynor (2002:25) is innovations that are carried out in the form of small changes such as modification, improvement, simplification, consolidation and improvement from those that have been there before in the company.

This research investigates the innovation capability of the firm at radical and incremental levels by innovation activities that undertaken by companies such as the results of innovation. According to Johannessen et al., (2001), the results of innovation can be classified into several types such product innovation, service innovation, process innovation, market innovation, logistics innovation, and organizational innovation. Product innovation refers to changes in product design, components and architecture (Avermaete et al., 2004; Neely et al., 2001) Service innovation is defined as a change in the way of serving customers and new services offered by the company (Geenhuizen and Indarti, 2005). Process innovation is an adaptation of existing product lines and implementation of new technologies (Avermaete et al., 2004; Neely et al., 2001).

Market innovation is the territorial expansion and penetration of new segments (Avermaete et al., 2004; Neely et al., 2001). Logistics innovation according to Geenhuizen and Indarti (2005) is a new logistics model for obtaining raw materials. The latest innovation results, organizational innovation, are new managerial systems, such as production control, quality management, organizational adaptation, decentralized authority and new ways of managing human resources (Avermaete et al., 2004; Neely et al., 2001). In this study, the innovation capability is examined based on the results of innovations that are tailored to the context of food and beverage industry companies in Indonesia, namely restaurant and café, manufacturing, and retail.

\subsubsection{Intellectual capital and innovation capability according to knowledge- based view}

In this study, intellectual capital and corporate innovation are linked based on the concept of knowledge-based view. Based on Grant (1996) concept of knowledge-based competition owned by a company, intellectual capital is a source of corporate capital that contribute to provides ideas for the types of innovation 
carried out (Mention, 2012) and also determines the company's ability to innovate (Subramaniam and Youndt, 2005; Wang and Chen, 2013).

\subsubsection{Intellectual capital according to knowledge-based view}

According to knowledge-based view by Grant (1996), knowledge is the most strategic power and resource for the company, because it influences competitive advantage (Omerzel and Gulev, 2011) and company success (DeNisi et al., 2003). This theory focuses on the role of companies in creating and applying knowledge through the activities of the company (Grant, 1996), as well as ways of gaining better knowledge from competitors (Choo and Bontis, 2002). That is because according to Teece et al. (1997), companies must face rapid environmental and economic changes by optimizing their internal and external sources.

Utilization of internal and external knowledge sources can bring the company in a favorable position, both in strategic decisions related to resource allocation (Scafarto et al., 2016), as well as results obtained from optimizing asset management such as the company's ability to innovate (Subramaniam and Youndt, 2005). Thus, it can be concluded that the definition of intellectual capital as a collection of knowledge assets derived from employee knowledge, structure and relationships (Kianto et al., 2010), based on the concept of knowledge-based view (Grant, 1996), is the key to creating corporate value (Kogut and Zander, 2009; Grant, 1996). Intellectual capital as an asset that contains company knowledge can influence a variety of corporate value creation such as project success (Handzic and Durmic, 2015), business performance (Bontis, 1999; Scafarto et al., 2016), and the company's ability to innovate (Subramaniam and Youndt, 2005; Wang and Chen, 2013).

\subsubsection{Innovation capability according to knowledge-based view}

Innovation is one of the ways companies do to achieve sustainable competitive advantage (Johannessen et al., 2001). According to Barney (1991), sustainable competitive advantage can be obtained when companies have resources with special criteria, such as valuable, rare, difficult to imitate and have no substitute. These types of resources include assets, capabilities, organizational processes, company attributes, information and knowledge (see Barney, 1991). Furthermore, from these types of resources, knowledge is the main resource (Grant, 1996), which influences the company's ability to innovate (Wang and Chen, 2013). That is because the ability of innovation is realized by the existence of knowledge management by the company (Kogut and Zander, 2009).

The innovation capability refers to the competence of companies in generating, developing and implementing new ideas, products, or processes that increase competitive advantage (Damanpour, 1992; Hult, Hurley, and Knight, 2004). The innovation capability also reflects the company's willingness to eliminate business routines that are not consistent with the new environment, as well as the application of new ideas that are suitable for competitive conditions (Hult et al., 2004; Menguc and Auh, 2006). Therefore, companies make the ability of innovation as a means for change, help in achieving company goals (Nguyen and Mohamed, 2011), and produce innovations for competitive advantage (Damanpour, 1992). 


\subsection{Hypotheses Development}

This research develops four (4) hypothesis which examine the effect of three dimensions of intellectual capital on the innovation capability. The three independent variables are human capital, structural capital, and relational capital. In this study, aside from being an independent variable, relational capital is also tested as a moderating variable. Dependent variable in this study is innovation capability.

Human capital refers to knowledge, skills and abilities that are in individuals and are used by individuals in their work (Schultz, 1961). The practice of human capital in company means applying the knowledge and capabilities of employees to act in new ways (Coleman, 1988). According to Chen and Huang (2009), these practices also play an important role and influence employee behavior in developing performance. Furthermore, individuals in companies emerge in a variety of skills, gaining new knowledge and abilities in creating new ways of thinking that are sources of new ideas in the company (Subramaniam and Youndt, 2005).

Previous studies also shows the effect of human capital on innovation has a positive effect (see Al-Dujaili, 2012; Chen and Huang, 2009; Nanggong and Indarti, 2016). Research by Chen et al. (2006) in the manufacturing sector shows that the individual aspects of the company are very important in creating innovation. Study of Nanggong and Indarti (2016) also provides evidence that assets located in employees such as skills and experience, have a positive effect on service company innovation in Indonesian context. This indicates that human capital plays an important role in the ability of companies to innovate, both in service companies and in manufacturing companies. Based on the description, we proposes the following hypothesis:

H1. Human capital has a positive effect on innovation capability.

Structural capital refers to organizational intellectuals (Winter, 1987) and all processes and technologies that function at the organizational level (Keenan and Aggestam, 2001) to store and transfer knowledge during business processes (Cabrita and Bontis, 2008). Tunc Bozbura (2004) revealed that structural capital is one of the foundations to create organizational learning, where the learning climate in organizations will encourage the process of innovation (Aramburu and Sáenz, 2011). To achieve innovation, companies need to consider the important role of organizational aspects such as culture, climate, learning, and organizational structure (Nanggong and Indarti, 2016).

Several empirical studies also prove the positive effect of structural capital on innovation (Al-Dujaili, 2012; Dost et al., 2016; Subramaniam and Youndt, 2005; Wang and Chen, 2013). For example, Subramaniam and Youndt (2005) revealed that human capital which is institutionalized and used through organizational structures, systems and processes will add to the company's innovation capability. Furthermore, the concept put forward by Hogan and Coote (2014) about organizational culture and innovation explains that organizational culture is an important trigger for the behavior of innovation creation, especially service companies in Australian context. The results of research conducted by Al-Dujaili (2012) in the context of manufacturing companies in Iraq also prove that all processes carried out in organizations that are reflected in structural capital will determine the process of organizational innovation. This indicates that structural 
capital has an important role in the process of creating innovation, both in the service sector and manufacturing. On this basis, the proposed hypothesis is as follows:

\section{H2. Structural capital has a positive effect on innovation capability.}

Relational capital is knowledge that is embedded in companies and derived through corporate relations (Engelman et al., 2017). Interactions carried out between internal company parties and employee interactions with external parties of the company (Delgado-Verde et al., 2011; Subramaniam and Youndt, 2005) will form a network system. Furthermore, the network system can assist companies in obtaining new sources of knowledge for strategic decisions, such as innovation decisions (Mention, 2012). This study refers to the concept of social capital according to Nahapiet and Ghoshal (1998) which states that the ability to collaborate and build interactions by individual unit leads to the formation of actual and potential resources, which in this study is referred to as relational capital. Thus, relational capital in this study is defined as knowledge assets obtained from collaboration, both internal and external to the company (Engelman et al., 2017; Wang and Chen, 2013).

Furthermore, Subramaniam and Youndt (2005) explain that the capital gained from interaction and collaboration is the most relevant component in encouraging the ability of innovation for an organization. According to Vega-Jurado et al. (2008), interactions between companies and other parties (i.e., consumers, suppliers and corporate partners) will bring in new knowledge from external sources, which in this study is defined as relational capital. Knowledge gained from company relations will be a source of ideas of types of innovation (Mention, 2012), and also determine the company's ability to innovate (Wang and Chen, 2013; Subramaniam and Youndt, 2005). Therefore, the hypothesis compiled is as follows:

H3. Relational capital has a positive effect on innovation capability.

According to Marr et al. (2004), firm value can be seen based on the accumulation of various types of knowledge and knowledge management practices. For example, the concept of utilizing the company's knowledge base by Bontis (1999) through interactions between fellow dimensions of intellectual capital, such as the interaction between human capital and relational capital (Wang and Chen, 2013). Research by Subramaniam and Youndt (2005) on intellectual capital and the ability of innovation in the context of services and manufacturing in America also revealed that the dimensions of intellectual capital, namely human capital, negatively affect the ability of corporate innovation. Human capital must interact with relational capital so that it has a positive effect on the ability of corporate innovation (Wang and Chen, 2013; Subramaniam and Youndt, 2005). Knowledge from interactions and collaborations contained in relational capital will affect employees' abilities in developing core knowledge, as well as other individual aspects such as employee skills, creativity and experience (Wang and Chen, 2013).

Previous literature studies on intellectual capital by Nahapiet and Ghoshal (1998) and Coleman (1988) provide disclosure related to the role of relational capital in the formation of human capital. Interactions conducted by employees in the company with customers and company partners affect the formation of employee knowledge (Nahapiet and Ghoshal, 1998), such as the formation of 
individual creativity (Hitt et al., 2001). According to Hitt et al. (2001), individual creativity develops through relationships built with external parties such as clients and corporate partners. Employees who have specific knowledge about customers will use that knowledge to serve customer needs better. Thus, the source of knowledge gained from collaboration and relationships affects the formation of individual specific knowledge which then benefits company-specific excellence (Hitt et al., 2001) and the innovation capability of the company (Wang and Chen, 2013). On this basis, the hypothesis proposed in this study are as follows:

H4. Relational capital has a positive moderate the effect of human capital on innovation capability.

\section{METHODOLOGY}

\subsection{Data collection}

The respondents of this study are the owners/managers/supervisors of Indonesian restaurant and café, manufacture, and retail companies. The province of Yogyakarta is selected to be a research site based on some considerations. The value added of the food and beverage industry to overall private sector economic activity has the highest growth compared to other regions in Java2. Also the province of Yogyakarta is one of regions in Indonesia which is in the first recommendation for culinary tourism destinations according to several travel guide sites (i.e., travel.detik.com, 2012; kuliner.panduanwisata.id, 2015; travel.dream.co.id, 2016; blog.reservasi.com, 2017).

To collect the data, we developed questionnaire with a semi-closed question structure and interviews related to company profiles and data. The questionnaire used in this study consisted of three parts. The first part is a question related to the demographic profile (gender, age, and education) of the respondent. The second part is a question about company profile. The third part is questions related to research variables. Data were collected in the period January - April 2018. The data collection process was carried out with the assistance of one enumerator from bachelor degree who had been trained.

\subsection{Sample description}

Sample in this study are three companies in the food and beverage industry such restaurants and café, manufacture, and retail. The selection of those three companies is based on the Standard Classification of Indonesian Industrial Origin (KBLI) 2015 version (Central Bureau of Statistic, 2015)3. The sampling technique used is purposive sampling by selecting based on criteria (Cooper and Schindler, 2013:359) as follows. First, restaurants and café, manufacture, and retail that have been established for minimum two years, because at that time the company's assets (such as intellectual capital) can be measured (Nanggong and Indarti, 2016). Second, restaurant and café, manufacture, and retail that are not from

\footnotetext{
2 The growth of gross regional domestic product the province of Yogyakarta is 29,35 percent (Central Bureau of Statistics of Yogyakarta, 2017), Jakarta 25,72 percent (Central Bureau of Statistics of Jakarta, 2017), Midle Java 16,66 percent (Central Bureau of Statistic of Midle Java, 2017), and West Java 23,8 percent (Central Bureau of Statistics of West Java, 2017).

${ }^{3}$ The food and beverage industry consists of the manufacturing sector (category c number 10), namely manufacturing and retail companies, and the sector of providing accommodation and food and beverage supply (category I number 56) such as restaurant and café companies.
} 
foreign licenses, because they already have standards by the licensee, and all intellectual capital management and innovation activities are carried out by overseas owners. Third, restaurant and café, manufacture, and retail are not in one branch, because they have the same characteristics even though located in different areas.

\subsection{Variable measurement}

The measurement of independent variables in this study are human capital, structural capital and relational capital. Human capital is simply stated as the aspect of knowledge possessed by company employees that is measured using ten items from Subramaniam and Youndt (2005) and Wang and Chen (2013). Structural capital is defined as institutionalized knowledge assets and experiences codified in organizations through culture, routines and structures (Engelman et al., 2017), measured using seven items from Engelman et al. (2017), also Wang and Chen (2013). Relational capital is knowledge assets related to internal and external relationships that are embedded in the company, as well as derived from company relations (Engelman et al., 2017). This variable is measured using five items from Engelman et al. (2017) and Subramaniam and Youndt (2005).

Dependent variable in this study is innovation capability which is defined as the ability of companies to transform ideas or knowledge into innovative outputs (Katila, 2002; Lawson and Samson, 2001). Innovation capability is measured using ten items as a result of the company's radical and incremental innovations (Johannessen et al., 2001) and the types of innovations carried out by the company (Indarti, 2012). All items of independent variable is measured using 5point Likert scale [ $1=$ strongly agree; $5=$ strongly disagree]. Items in dependent variable use 5 -point Likert scale [ $1=$ very rare; 5 = very often].

\section{RESULT AND DISCUSSION}

\subsection{Company profile}

Table 3 presents the total number of companies that were respondents in this study were 120 companies, with 63 of them being the most are restaurants and café. The difference in the number of companies is caused by factors related to findings during the data collection process. Many retail companies refused to provide information on the grounds of maintaining company privacy while restaurant and café companies are the easiest to access because they are grouped in one place.

Table 3. Company Profile

\begin{tabular}{lcccccccc}
\hline \multirow{2}{*}{ Category } & \multicolumn{2}{c}{$\begin{array}{c}\text { Restaurant } \\
\text { and café }\end{array}$} & \multicolumn{2}{c}{ Manufacture } & \multicolumn{2}{c}{ Retail } & \multicolumn{2}{c}{ Total } \\
\cline { 2 - 11 } & $\mathrm{N}$ & $\%$ & $\mathrm{~N}$ & $\%$ & $\mathrm{~N}$ & $\%$ & $\mathrm{~N}$ & $\%$ \\
\hline Type & 63 & 53 & 42 & 35 & 15 & 13 & 120 & 100 \\
Age & & & & & & & & \\
$2-5$ years old & 53 & 84,1 & 8 & 19,0 & 5 & 33,3 & 66 & 55 \\
6-10 years old & 8 & 12,7 & 9 & 21,4 & 3 & 20,0 & 20 & 16,7 \\
$>10$ years old & 2 & 3,2 & 25 & 59,5 & 7 & 46,7 & 34 & 28,3 \\
Total & 63 & 100 & 42 & 100 & 15 & 100 & 120 & 100 \\
Type of product that company offers & 1 & 1,6 & 34 & 81,0 & 11 & 73,3 & 46 & 38,3 \\
Food & 1 & & & & & &
\end{tabular}




\begin{tabular}{lcccccccc}
\hline \multirow{2}{*}{ Category } & \multicolumn{2}{c}{$\begin{array}{c}\text { Restaurant } \\
\text { and café }\end{array}$} & \multicolumn{2}{c}{ Manufacture } & \multicolumn{2}{c}{ Retail } & \multicolumn{2}{c}{ Total } \\
\cline { 2 - 11 } & $\mathrm{N}$ & $\%$ & $\mathrm{~N}$ & $\%$ & $\mathrm{~N}$ & $\%$ & $\mathrm{~N}$ & $\%$ \\
\hline Beverage & 4 & 6,3 & 5 & 11,9 & - & - & 9 & 7,5 \\
Food and Beverage & 58 & 92,1 & 3 & 7,1 & 4 & 26,7 & 65 & 54,2 \\
Total & 63 & 100 & 42 & 100 & 15 & 100 & 120 & 100 \\
The average of emloyee & 12 & - & 11 & - & 10 & - & 11 & - \\
\hline
\end{tabular}

The age of most companies is in the age range of two to five years (66 companies), dominated by restaurants and café. Age two to five years can be categorized as a business that has just started or is young, so companies must aggressively innovate to compete and maintain the market. Next is companies that over 10 years old (34 companies) where the majority are manufacture (25 companies). Respondents stated that most of the businesses they run are inherited from parents or family businesses that are managed from generation to generation.

As many as 54,2 percent of the companies in this study offered food and beverage products, where restaurants and café were the most number of companies (58 companies or 92 percent). The average of employee in restaurant and café are 12, manufacture are 11 , and retail are 10 . Overall, from the total 120 companies, an average of 11 workers were obtained. These findings indicate that the majority of respondents in this study belong to small companies based on the average number of employees (Nanggong and Indarti, 2016).

\subsection{Descriptive statistic}

The results in Table 4 informs that from scale 1-5 score, the mean for each variable has the same category and the variation of the answers given by respondents to each variable in this study is included at moderate level. The standard deviation value of human capital is 0,43 , structural capital is 0,91 , and relational capital is 0,55 , while the innovation capability is 0,73 . The standard deviation values of this study which range $0,4-0,9$ indicate a sufficient variation in the distribution of sample data to its average.

\section{Table 4. Result of Descriptive Statistic and Correlation}

\begin{tabular}{lccccccc}
\hline \multicolumn{1}{c}{ Variable } & Average & SD & Mode & HC & SC & RC & IN \\
\hline $\begin{array}{l}\text { Human capital } \\
\text { (HC) }\end{array}$ & 4,56 & 0,43 & 5 & 1 & & & \\
$\begin{array}{l}\text { Structural } \\
\text { capital (SC) }\end{array}$ & 3,55 & 0,91 & 5 & $-0,055$ & 1 & & \\
$\begin{array}{l}\text { Relational } \\
\text { capital (RC) }\end{array}$ & 4,36 & 0,55 & 5 & $0,449^{* * *}$ & $0,390^{* * *}$ & 1 & \\
$\begin{array}{l}\text { Innovation } \\
\text { capability (IN) }\end{array}$ & 3,69 & 0,73 & 4 & 0,073 & $0,652^{* * *}$ & $0,343^{* * *}$ & 1 \\
\hline $\mathrm{N}=120 ; \mathrm{p}^{* * *} \leq 0,01, \mathrm{p}^{* *} \leq 0,05, \mathrm{p}^{*} \leq 0,1$ & & & &
\end{tabular}

All independent variables in this study have the same mode value, which is a score of 5 means that respondents' answers that often appear are "very agree". The value of the dependent variable mode is a score of 4 which means that the respondents' answers that appear frequently are "often". Another result from Table 4 is the correlation value between variables with range $-0,05-0,65$ at significance 
level 1 percent. The existence of high correlation on the relationship between structural capital and innovation capability $\left(0,64^{* * *}\right)$ is not a problem in testing the research model because the relationship between two variables is tested in a hypothesis. Moreover, the correlation among variables in this study is included in the moderate category (Hair et al., 2014) and does not endanger the testing of research models.

\subsection{Hypotheses testing}

Hypothesis testing is done by hierarchical regression analysis techniques or in stages (seeError! Reference source not found.), where Model one (M1) explains the testing of independent variables on the dependent variable and Model two (2) tests the role of the relational capital as moderator. Hypothesis one (H1) says that human has positive effect on innovation capability. Based on Error! Reference source not found. Model one (M1), human capital has not significantly effect on innovation capability $(\beta=-0,002 ; t=-0,028 ; p>0.1$ percent). Thus, Hypothesis one (H1) of this study is not supported. These results do not support the study of Cabello-Medina et al. (2011) and Nanggong and Indarti (2016) who found a positive influence of human capital on innovation in companies.

Table 5. Result of Hypothesis Testing

\begin{tabular}{|c|c|c|c|c|c|c|}
\hline \multirow{2}{*}{ Variable } & \multicolumn{3}{|c|}{ Model 1} & \multicolumn{3}{|c|}{ Model 2} \\
\hline & $B$ & $T$ & Sig & $B$ & $T$ & Sig \\
\hline $\begin{array}{l}\text { Independent: } \\
\text { human capital (HC) } \\
\text { structural capital } \\
\text { (SC) } \\
\text { relational capital } \\
\text { (RC) }\end{array}$ & $\begin{array}{l}-0,002 \\
0,560^{\star * *} \\
0,230^{\star * *}\end{array}$ & $\begin{array}{l}-0,028 \\
7,342^{\star * *} \\
2,773^{* * *}\end{array}$ & $\begin{array}{l}0,978 \\
0,000 \\
0,000\end{array}$ & $\begin{array}{l}0,040 \\
0,561^{* * *} \\
0,292^{* * *}\end{array}$ & $\begin{array}{l}0,070 \\
7,278^{\star * *} \\
0,389\end{array}$ & $\begin{array}{l}0,944 \\
0,000 \\
0,698\end{array}$ \\
\hline $\begin{array}{l}\text { Moderating effect: } \\
\text { human capital }(\mathrm{HC}) \times \\
\text { relational capital } \\
\text { (RC) }\end{array}$ & & & & $-0,084$ & $-0,075$ & 0,940 \\
\hline Adjusted $\mathrm{R}^{2}$ & \multicolumn{3}{|c|}{0,459} & \multicolumn{3}{|c|}{0,454} \\
\hline $\mathrm{F}$ & \multicolumn{3}{|c|}{$34,63^{* * *}$} & \multicolumn{3}{|c|}{$25,75^{\star \star \star}$} \\
\hline
\end{tabular}

Based on the number of employees, the companies that were sampled in this study were classified as small and medium enterprises with an average of 11 employees (see Error! Reference source not found.) where in this type of company, the company's leadership is controlled by the owner (Indarti, 2012). Based on interviews, 86 percent of restaurant and café, 98 percent of manufactures, and 93 percent of retail companies stated that decisions related to innovation were determined by the owners. Thus, employees are not directly involved in the idea of innovation, because it is only discussed by company leaders (Deichmann and Stam, 2015).

Hypothesis two $(\mathrm{H} 2)$ is also seen in Model one (M1) Table 5 which shows the effect of structural capital on innovation capability. The standardization coefficient of structural capital is shown by the $\beta$ value of 0,560 at the one percent 
significance level $(p=<0,01)$. This result means that structural capital positively influences innovation capability. This study identifies structural capital as one of the knowledge that comes from the internal company and in the system, routines and culture in the company. One of the ways companies implement structural capital practices is to internalize the company's values to optimize innovation capabilities. The results of data collection stated that from 120 respondents, 95 percent of restaurants and café, 52 percent of manufactures, and 60 percent of retailers implemented a method of internalizing company value. This percentage proves that most companies in the food and beverage industry have structural capital that can be optimized as a source of knowledge for innovation.

Furthermore, Hypothesis three (H3) testing based on Model One (1) in Error! Reference source not found. also shows that relational capital has a positive effect on innovation capability proved to be significant $(\beta=0,230 ; t=2.773 ; p<0,01)$. The concept of relational capital was identified by looking at interactions and forms of corporate cooperation with external parties such as consumers, suppliers, distributors, banks, karaoke, health clinics, event organizers, educational institutions, social institutions, research institutions, social communities and cigarette companies. With these relationships, over the last two years, 62 percent of restaurants and café, 21 percent of manufactures, and 40 percent of retail establish cooperation through the provision of joint activities such as breaking fast events and company anniversary celebrations. Through these activities, companies can communicate and share information with relations more closely, and try to take the opportunity to obtain different knowledge (García-Granero et al., 2015). Thus, the company take the advantage of different knowledge to support innovation capability.

In addition to testing the effect of the independent variable on the dependent, this study also examined the effect of the moderating variable. The type of moderation tested is quasi moderation in which the relational capital variable acts as an independent and moderator variable. Hypothesis four $(\mathrm{H} 4)$ is that relational capital positively moderates the effect of human capital on the ability of innovation. However, the results of the regression test showed that human capital had no positive effect on the ability of innovation ( $\mathrm{H} 1$ was not supported). Therefore, testing the effects of moderation ( $\mathrm{H} 4)$ in this study cannot be continued. Testing the Model (2) interaction effect also states that the results are not significant $(\beta=-$ $0.084 ; \mathrm{t}=-0.075 ; \mathrm{p}>0.1)$. This finding does not support the research of Subramaniam and Youndt (2005) and Wang and Chen (2013) which states that human capital must interact with relational capital so that the influence of human capital on the ability of innovation to be positive.

This result also does not support the study of Cabello-Medina et al. (2011) which states that social relations owned by companies can increase human capital. That is because the relationships between employees and relations with external parties do not determine the increase in the quality of human capital in restaurant and café companies, manufactures and retailers. Respondents also revealed that the specific skills acquired by employees are derived from training and are determined by the length of service of employees. The longer the employee works in the company, the more competent the job will be. Therefore, the relationship of interactions conducted by employees with other parties is not related to the development of employee skills in the company. 
From the results of testing four hypothesis, it can be concluded that two hypothesis are supported $(\mathrm{H} 2$ and $\mathrm{H} 3)$ and the other two are not supported $(\mathrm{H} 1$ and $\mathrm{H} 4$ ). This finding explains that not all dimensions of intellectual capital have a positive effect on the ability of corporate innovation.

\section{CONCLUSION}

This research is aimed to examining the effect of intellectual capital on innovation capability where the object of research focuses on three companies in the food and beverage industry in Indonesia such restaurant and café, manufacture, and retail. The results prove that structural capital and relational capital has positive effect on innovation capability in the food and beverage industry in Indonesia. This finding reinforces the previous empirical study (AlDujaili, 2012; Nanggong and Indarti, 2016) which states that the company's assets contained in the organizational structure and system have a positive effect on innovation by the company. Thus, structural capital positively influences the ability of company to innovate (Subramaniam and Youndt, 2005; Wang and Chen, 2013).

Another dimension of intellectual capital that plays an important role for innovation capability is relational capital. According to Ministry of Industry (2017), the food and beverage industry in Indonesia is in competitive competition so it requires a variety of knowledge for innovation sources. Knowledge gained from interaction and collaboration is known to contribute significantly to the creation of ideas related to innovation in the company. Therefore, in line with the context of this study, it was found that the role of relational capital influences the ability of innovation in the food and beverage industry in Indonesia. The results of this study support the research of Subramaniam and Youndt (2005) and Wang and Chen (2013) which prove the positive influence of relational capital (i.e., social interaction) on the ability of corporate innovation.

In addition, other findings from this study indicate that not all dimensions of intellectual capital affect the ability of innovation. In this study, human capital has not significantly effect on innovation capability. The result do not support the study of Cabello-Medina et al. (2011), Al-Dujaili (2012), and Nanggong and Indarti (2016), which stated that the aspects of employees (i.e., intelligence and skills) had a positive effect on innovation. Ideas and decisions of innovation focused on the owners and leaders which are thought to be factors that cause human capital does not significantly influence innovation capability (see Deichmann and Stam, 2015).

Furthermore, this research has not been able to prove the role of relational capital on the effect of human capital on the ability of innovation. Moderation testing cannot be done because human capital has not been proven to have a significant positive effect on innovation capability. The role of knowledge gained from relationships and collaboration does not affect the development of individual employee knowledge for the company's innovation capabilities. This is because the formation of human capital (i.e., employee skills and competencies) in the context of the company in this study is not related to collaboration and 
relationships, but to the development and training provided by the company, as well as the length of service of employees.

In theory, this research contributes to strengthening knowledge-based theory (Grant, 1996) on the creation of corporate value such intellectual capital that effects on innovation capability, especially in restaurant and café, manufacture, and retail companies. This study found that in those three companies, aspects of human capital such as intelligence, ability and skills, did not significantly influence the ability of innovation. That is because innovation decisions are not related to employees but rather the owners and leaders of the company. However, structural capital and relational capital are important knowledge assets because they have positive effect on innovation capability.

Therefore, structural capital and relational capital must be optimized because play an important role for innovation capabilities in restaurant and café, manufacture, and retail. Furthermore, the formation of human capital aspects such employee skills in food and beverage industry companies is not related to relations and collaboration. This is due to the creation of employee skills related to training and development by the company, as well as the employee's service period. Thus, the interaction between human capital and relational capital does not significantly influence the innovation capability.

This research has several limitations to follow up on future research. First, this study only identifies the effect of the intellectual capital dimensions directly and moderation on innovation capability. Subsequent research can explore more deeply the relationship among dimensions of intellectual capital (Mention, 2012) in influencing innovation capability, both mediation and moderation. Second, this study refers to the categorization of the dimensions of intellectual capital according to Buenechea-Elberdin (2017) where the dimensions consist of human capital, structural capital, and relational capital. Future research can use different dimensions, adjusted for the research context.

Third, this study only examines the effect of intellectual capital on innovation capability based on six types of innovation results. Future research can investigate the effect of intellectual capital on other aspects of innovation such innovation process (Mention, 2012). Fourth, this research was conducted three types companies (restaurants and café, manufacture, and retail) but did not specifically differentiate them. Future research can be carried out in different firm context and identify the role of intellectual capital in the type of companies (i.e., differences between manufactures and services).

\section{REFERENCE}

Al-Dujaili, M., 2012. Influence of Intellectual Capital in the Organizational Innovation. International Journal of Innovation, Management and Technology, 3(2), 128-135.

Amelia, L., Purbolaksono, A, and Syahayani, Z., 2017. Analisis Peta Industri Makanan dan Minuman di Indonesia (pp. 1-33). 1-33. The Indonesian Institute.

Andreeva, T., \& Garanina, T., 2016. Do all elements of intellectual capital matter for organization performance? Evidence from Russian context. Journal of Intellectual Capital, 17(2), 397-412. 
Aramburu, N. and Sáenz, J., 2011. Structural capital, innovation capability, and size effect: An empirical study. Journal of Management and Organization, 17(3), 307-325. https://doi.org/10.1017/s1833367200001498

Avermaete, T., Viaene, J., Morgan, E. J., Pitts, E., Crawford, N. and Mahon, D., 2004. Determinants of product and process innovation in small food manufacturing firms. Trends in Food Science and Technology, 15(10), 474-483. https://doi.org/10.1016/j.tifs.2004.04.005

Barney, J., 1991. Firm Resources and Sustained Competitive Advantage. Journal of Management, 17(1), 99-120. https://doi.org/10.1177/014920639101700108

Bontis, N., 1999. Managing organizational knowledge by diagnosing intellectual capital: Framing and advancing the state of the field. International Journal of Technology Management, 18(5), 433-462.

https://doi.org/10.1504/ijtm.1999.002780

Bontis, N., William Chua Chong, K. and Richardson, S., 2000. Intellectual capital and business performance in Malaysian industries. Journal of Intellectual Capital, 1(1), 85-100. https://doi.org/10.1108/14691930010324188

Buenechea-Elberdin, M., 2017. Structured literature review about intellectual capital and innovation. Journal of Intellectual Capital, 18(2), 265-285.

https://doi.org/10.1108/JIC-07-2016-0069

Cabello-Medina, C., López-Cabrales, Á., and Valle-Cabrera, R., 2011. Leveraging the innovative performance of human capital through HRM and social capital in Spanish firms. International Journal of Human Resource Management, 22(4), 807-828. https://doi.org/10.1080/09585192.2011.555125

Cabrita, M. D. R. and Bontis, N., 2008. Intellectual capital and business performance in the Portuguese banking industry. International Journal of Technology Management, 43(1-3), 212-237.

https://doi.org/10.1504/IJTM.2008.019416

Carmona-Lavado, A., Cuevas-Rodríguez, G. and Cabello-Medina, C., 2013. Intellectual capital and new product development performance: The mediating role of organizational learning capability. Industry and Innovation, 20(2), 133-156. https://doi.org/10.1080/13662716.2013.771482

Central Bureau of Statistic. 2015. Klasifikasi Baku Lapangan Usaha Indonesia 2015. Jakarta: Badan Pusat Statistik.

Central Bureau of Statistic of Midle Java. 2017. Gross Regional Domestic Product by Industrian Origin [Produk Domestik Regional Bruto Menurut Lapangan Usaha] The Province Midle Java 2012-2016. Central Bureau of Statistics, 1-59. https://doi.org/Katalog BPS 9302020.33

Central Bureau of Statistics of Jakarta. 2017. Gross Regional Domestic Product by Industrian Origin [Produk Domestik Regional Bruto Menurut Lapangan Usaha] DKI Jakarta 2012-2016 (pp. 1-86). 1-86. https://doi.org/Katalog BPS 9302001.31

Central Bureau of Statistics of West Java. 2017. Gross Regional Domestic product by Industrian Origin [Produk Domestik Regional Bruto Menurut Lapangan Usaha] The Province West Java 2012-2016. pp. 1-75. https://doi.org/Katalog BPS 9302001.32 
Central Bureau of Statistics of Yogyakarta. 2017. Gross Regional Domestic Product by Industrian Origin [Produk Domestik Regional Bruto Menurut Lapangan Usaha] The Province of Yogyakarta. https://doi.org/Katalog BPS 9302021.34

Chen, C. J. and Huang, J. W., 2009. Strategic human resource practices and innovation performance - The mediating role of knowledge management capacity. Journal of Business Research, 62(1), 104-114.

https://doi.org/10.1016/j.jbusres.2007.11.016

Chen, M. C., Cheng, S. J. and Hwang, Y., 2005. An empirical investigation of the relationship between intellectual capital and firms' market value and financial performance. Journal of Intellectual Capital, 6(2), 159-176.

https://doi.org/10.1108/14691930510592771

Chen, Y. S., James Lin, M. J., and Chang, C. H., 2006. The influence of intellectual capital on new product development performance - The manufacturing companies of Taiwan as an example. Total Quality Management and Business Excellence, 17(10), 1323-1339. https://doi.org/10.1080/14783360601058979

Choo, C. W. and Bontis, N. (Eds.)., 2002. The Strategic Management of Intellectual Capital and Organizational Knowledge. Oxford University Press.

Cleary, P. and Quinn, M., 2016. Intellectual capital and business performance: An exploratory study of the impact of cloud-based accounting and finance infrastructure. Journal of Intellectual Capital, 17(2), 255-278. https://doi.org/10.1108/JIC-06-2015-0058

Coleman, J. S., 1988. Supplement: Organizations and Institutions: Sociological and Economic Approaches to the. Source: American Journal of Sociology, 94(1988), 95-120. Retrieved from https://docs.wixstatic.com/ugd/b76639_d4bc452561294ab1a646bf19dc7cacb1.pdf Cooper, D. R. and Schindler, P. S., 2013. Business Research Methods (12th, Ed.). USA: McGraww-Hill.

Costa, R. V., Fernández-Jardon Fernández, C. and Figueroa Dorrego, P., 2014. Critical elements for product innovation at Portuguese innovative SMEs: An intellectual capital perspective. In Knowledge Management Research and Practice, 12. https://doi.org/10.1057/kmrp.2014.15

Damanpour, F., 1992. Organizational Size \& Innovation. Organization Studies, 13(3), 375-402. https://doi.org/10.1177/017084069201300304

Deichmann, D. and Stam, D., 2015. Leveraging transformational and transactional leadership to cultivate the generation of organization-focused ideas. Leadership Quarterly, 26(2), 204-219. https://doi.org/10.1016/j.leaqua.2014.10.004

Delgado-Verde, M., Castro, G. M. and Navas-López, J. E., 2011. Organizational knowledge assets and innovation capability: Evidence from Spanish manufacturing firms. Journal of Intellectual Capital, 12(1), 5-19. https://doi.org/10.1108/14691931111097890

DeNisi, A. S., Hitt, M. A. and Jackson, S. E., 2003. The knowledge-based approach to sustainable competitive advantage. Managing Knowledge for Sustained Competitive Advantage: Designing Strategies for Effective Human Resource Management, 3-33.

Dewar, R. D. and Dutton, J. E., 1986. The Adoption of Radical and Incremental 
Innovations: An Empirical Analysis. Management Science, 32(11), 1422-1433. https://doi.org/10.1287/mnsc.32.11.1422

Dost, M., Badir, Y. F., Ali, Z. and Tariq, A., 2016. The impact of intellectual capital on innovation generation and adoption. Journal of Intellectual Capital, 17(4), 675695. https://doi.org/10.1108/JIC-04-2016-0047

Dumay, J., Guthrie, J. and Puntillo, P., 2015. IC and public sector: a structured literature review. Journal of Intellectual Capital, 16(2), 267-284.

https://doi.org/10.1108/JIC-02-2015-0014

Engelman, R. M., Fracasso, E. M., Schmidt, S. and Zen, A. C., 2017. Intellectual capital, absorptive capacity and product innovation. Management Decision, 55(3), 474-490. https://doi.org/10.1108/MD-05-2016-0315

Everett M. Rogers., 2003. Diffusion of innovations (Fifth Edit). New York: Free Press.

Fan, I. Y. H. and Lee, R. W. B., 2016. Intellectual capital-based innovation planning: empirical studies using wiNK model. Journal of Intellectual Capital, 17(3), 553-569. https://doi.org/10.1108/JIC-12-2015-0116

Ferenhof, H. A., Durst, S., Bialecki, M. Z. and Selig, P. M., 2015. Intellectual capital dimensions: state of the art in 2014. Journal of Intellectual Capital, 16(1), 58-100. https://doi.org/10.1108/JIC-12-2013-0118

Fleming, L., 2001. Recombinant uncertainty in technological search. Management Science, 47(1), 117-132. https://doi.org/10.1287/mnsc.47.1.117.10671

García-Granero, A., Llopis, Ó., Fernández-Mesa, A. and Alegre, J., 2015. Unraveling the link between managerial risk-taking and innovation: The mediating role of a risk-taking climate. Journal of Business Research, 68(5), 1094-1104. https://doi.org/10.1016/j.jbusres.2014.10.012

Gaynor, G. H. (Gus). 2002. Innovation by Design: What It Takes to Keep Your Company on the Cutting Edge. USA: American Management Association.

Geenhuizen, M. Van. and Indarti, N., 2005. Knowledge as a Critical Resource in Innovation among Small Furniture Companies in Indonesia: An Exploration. Gadjah Mada International Journal of Business, 7(3), 371. https://doi.org/10.22146/gamaijb.5581

Grant, R. M., 1996. Toward a knowledge based theory of the firm. Strategic Management Journal, 17, 109-122.

Guthrie, J. and Petty, R., 2000. Intellectual capital: Australian annual reporting practices. Journal of Intellectual Capital, 1(3), 241-251.

https://doi.org/10.1108/14691930010350800

Hair, J. J. F., Black, W. C., Babin, B. J. and Anderson, R. E., 2014. Multivariate Data Analysis (MVDA) (Seventh Ed). https://doi.org/10.1002/9781118895238.ch8

Handzic, M. and Durmic, N., 2015. Knowledge Management, Intellectual Capital and Project Management : Connecting the Dots. The Electronic Journal of Knowledge Management, 13(1), 51-61. 
Hitt, M. A., Bierman, L., Shimizu, K. and Kochhar, R., 2001. Direct and moderating effects of human capital on strategy and performance in professional service firms: A resource-based perspective. Academy of Management Journal, 44(1), 13-28. https://doi.org/10.2307/3069334

Hogan, S. J. and Coote, L. V., 2014. Organizational culture, innovation, and performance: A test of Schein's model. Journal of Business Research, 67(8), 1609-1621. https://doi.org/10.1016/j.jbusres.2013.09.007

Hsu, Y. H. and Fang, W., 2009. Intellectual capital and new product development performance: The mediating role of organizational learning capability.

Technological Forecasting and Social Change, 76(5), 664-677.

https://doi.org/10.1016/j.techfore.2008.03.012

Huggins, R., 2010. Network resources and knowledge alliances: Sociological perspectives on inter-firm networks as innovation facilitators. International Journal of Sociology and Social Policy, 30(9-10), 515-531.

https://doi.org/10.1108/01443331011072271

Hult, G. T. M., Hurley, R. F. and Knight, G. A., 2004. Innovativeness: Its antecedents and impact on business performance. Industrial Marketing Management, 33(5), 429-438. https://doi.org/10.1016/j.indmarman.2003.08.015

Indarti, N., 2012. Does knowledge stickiness affect a firm's innovation capability?: Empirical evidence from Indonesian furniture SMEs. Gadjah Mada International Journal of Business, 14(1), 17-33. https://doi.org/10.22146/gamaijb.5436

Johannessen, J. A., Olsen, B. and Lumpkin, G. T., 2001. Innovation as newness: What is new, how new, and new to whom? European Journal of Innovation Management, 4(1), 20-31. https://doi.org/10.1108/14601060110365547

Katila, R., 2002. New product search over time: Past ideas in their prime? Academy of Management Journal, 45(5), 995-1010.

Keenan, J. and Aggestam, M., 2001. Corporate governance and intellectual capital: Some conceptualisations. Corporate Governance, 9(4), 259-275. https://doi.org/10.1111/1467-8683.00254

Kianto, A., Hurmelinna-Laukkanen, P. and Ritala, P., 2010. Intellectual capital in service- and product-oriented companies. Journal of Intellectual Capital, 11(3), 305-325. https://doi.org/10.1108/14691931011064563

Kogut, B. and Zander, U., 2009. Knowledge of the firm. Combinative capabilities, and the replication of technology. Knowledge in Organisations, (August), 17-36. https://doi.org/10.1287/orsc.3.3.383

Köhler, C., Sofka, W. and Grimpe, C., 2012. Selective search, sectoral patterns, and the impact on product innovation performance. Research Policy, 41(8), 13441356. https://doi.org/10.1016/j.respol.2012.03.020

Kramer, J. P., Marinelli, E., lammarino, S. and Diez, J. R., 2011. Intangible assets as drivers of innovation: Empirical evidence on multinational enterprises in German and UK regional systems of innovation. Technovation, 31(9), 447-458. https://doi.org/10.1016/j.technovation.2011.06.005 
Lawson, B. and Samson, D., 2001. Developing innovation capability in organizations: A dynamic capabilities approach. International Journal of Innovation Management, 5(3), 377-400.

Leitner, K. H., 2011. The effect of intellectual capital on product innovativeness in SMEs. International Journal of Technology Management, 53(1), 1-18. https://doi.org/10.1504/IJTM.2011.037235

Lev, B., 2001. Intangibles: management, measurement and reporting. Washington: Brooking Institutions Press.

Marr, B., Schiuma, G. and Neely, A., 2004. Intellectual capital - defining key performance indicators for organizational knowledge assets. Business Process Management Journal, 10(5), 551-569.

https://doi.org/10.1108/14637150410559225

Marzo, G. and Scarpino, E., 2016. Exploring intellectual capital management in SMEs: an in-depth Italian case study. Journal of Intellectual Capital, 17(1), 27-51. https://doi.org/10.1108/JIC-09-2015-0075

Menguc, B. and Auh, S., 2006. Creating a firm-level dynamic capability through capitalizing on market orientation and innovativeness. Journal of the Academy of Marketing Science, 34(1), 63-73. https://doi.org/10.1177/0092070305281090

Mention, A.-L., 2012. Intellectual Capital, Innovation and Performance: a Systematic Review of the Literature. Business and Economic Research, 2(1), pp.1-37. https://doi.org/10.5296/ber.v2i1.1937

Ministry of Industry., 2017. Analisis Perkembangan Industri [Analysis of industry development]. Jakarta: Pusat Data dan Informasi Kementerian Perindustrian 2017.

Nahapiet, J. and Ghoshal, S., 1998. Social Capital, Intellectual Capital, and the Organizational Advantage. Academy of Management Review, 23(2), 242-266.

Nanggong, A. and Indarti, N., 2016. The effect of intangible resources on innovation in service firms with the role of absorptive capacity as a moderating variable. 2016 IEEE International Conference on Management of Innovation and Technology, ICMIT 2016, 7-12. https://doi.org/10.1109/ICMIT.2016.7604999

Neely, A., Filippini, R., Forza, C., Vinelli, A. and Hii, J., 2001. A framework for analysing business performance, firm innovation and related contextual factors: Perceptions of managers and policy makers in two European regions. Integrated Manufacturing Systems, 12(2), 114-124.

https://doi.org/10.1108/09576060110384307

Nguyen, H. N. and Mohamed, S., 2011. Leadership behaviors, organizational culture and knowledge management practices: An empirical investigation. Journal of Management Development, 30(2), 206-221.

https://doi.org/10.1108/02621711111105786

Oke, A., 2007. Innovation types and innovation management practices in service companies. International Journal of Operations and Production Management, 27(6), 564-587. https://doi.org/10.1108/01443570710750268

Omerzel, D. G. and Gulev, R. E., 2011. Knowledge Resources and Competitive Advantage. Managing Global Transitions, 9(4), 335-354. 
Roos, J., Roos, G., Edvinsson, L. and Dragonetti, N. C., 1997. Intellectual Capital: Navigating in the new business landscape (1st ed.; A. Editorial, Mendham, and Suffolk, Eds.). https://doi.org/10.1007/978-1-349-14494-5

Scafarto, V., Ricci, F. and Scafarto, F., 2016. Intellectual capital and firm performance in the global agribusiness industry: the moderating role of human capital. Journal of Intellectual Capital, 17(3),1-17.

Schultz, T. W., 1961. Investment in Human Capital. The American Economic Review, 51, 1-17.

Subramaniam, M. and Youndt, M. A., 2005. The influence of intellectual capital on the types of innovative capabilities. Academy of Management Journal, 48(3), 450 463. https://doi.org/10.1108/IMDS-06-2015-0229

Teece, D. J., Pisano, G. and Shuen, A., 1997. Dynamic capabilities and strategic management: organizing for innovation and growth. Strategic Management Journal, 18(7), 509-533.

Tsai, W., 2001. Knowledge transfer in intraorganizational networks: Effects of network position and absorptive capacity on business unit innovation and performance. Academy of Management Journal, 44(5), 996-1004.

https://doi.org/10.2307/3069443

Tunc Bozbura, F., 2004. Measurement and application of intellectual capital in Turkey. The Learning Organization, 11(4), 357-367.

https://doi.org/10.1108/09696470410538251

Tushman, M. and Nadler, D., 1986. Organizing for Innovation. California Management Review, 28(3), 74-92. https://doi.org/10.2307/41165203

Varis, M. and Littunen, H., 2010. Types of innovation, sources of information and performance in entrepreneurial SMEs. European Journal of Innovation Management, 13(2), pp.128-154. https://doi.org/10.1108/14601061011040221

Vega-Jurado, J., Gutiérrez-Gracia, A., Fernández-de-Lucio, I. and ManjarrésHenríquez, L., 2008. The effect of external and internal factors on firms' product innovation. Research Policy, 37(4), 616-632.

https://doi.org/10.1016/j.respol.2008.01.001

Wang, D. and Chen, S., 2013. Does intellectual capital matter? High-performance work systems and bilateral innovative capabilities. International Journal of Manpower, 34(8), 861-879. https://doi.org/10.1108/IJM-07-2013-0167

Winter, S. G., 1987. Knowledge and competence as strategic assets. In The Competitive Challenge: Strategies of Industrial Innovation and Renewal, 165-188. https://doi.org/10.1016/b978-0-7506-9850-4.50013-0

Wu, X. and Sivalogathasan, V., 2013. Intellectual Capital for Innovation Capability: A Conceptual Model for Innovation. International Journal of Trade, Economics and Finance, 4(3), 139-144. https://doi.org/10.7763/ijtef.2013.v4.274

Zerenler, M., Burak Hasiloglu, S. and Sezgin, M., 2008. Intellectual Capital and Innovation Performance: Empirical Evidence in the Turkish Automotive Supplier. Journal of Technology Management and Innovation, 3(4), 31-40. Retrieved from http://www.jotmi.org 